\title{
An investigation of the origins of reactive gaseous mercury in the Mediterranean marine boundary layer
}

\author{
F. Sprovieri, I. M. Hedgecock, and N. Pirrone \\ Institute for Atmospheric Pollution Research, Rende Section, Rende, CS, Italy \\ Received: 29 October 2009 - Published in Atmos. Chem. Phys. Discuss.: 19 November 2009 \\ Revised: 20 April 2010 - Accepted: 21 April 2010 - Published: 28 April 2010
}

\begin{abstract}
Atmospheric mercury species concentrations were measured during two oceanographic cruise campaigns covering the Adriatic Sea, the first during the autumn in 2004 and the second in the summer of 2005. The inclement weather during the autumn campaign meant that no clear in-situ production of oxidised gas phase mercury was seen. Events where high values of $\mathrm{Hg}_{(\mathrm{g})}^{\mathrm{II}}$ and/or $\mathrm{Hg}$ associated with particulates $\left(\mathrm{Hg}^{\mathrm{P}}\right)$ were observed, could be linked to probable anthropogenic emission source areas. During the summer campaign however, the by now rather familiar diurnal variation of $\mathrm{Hg}_{(\mathrm{g})}^{\mathrm{II}}$ concentration, with maxima around midday, was observed. Again there were events when high $\mathrm{Hg}_{(\mathrm{g})}^{\mathrm{II}}$ and particulates $\left(\mathrm{Hg}^{\mathrm{P}}\right)$ concentrations were seen which did not fit with the pattern of daily in-situ $\mathrm{Hg}_{(\mathrm{g})}^{\mathrm{II}}$ production. These events were traceable, with the help of back trajectory calculations, to areas of anthropogenic emissions. The back trajectories for all the events during which high $\mathrm{Hg}$ species concentrations were encountered showed that the airmass being sampled had passed near port areas in the previous $24 \mathrm{~h}$. Not all these ports are associated with major industrial installations, it is possible therefore (bearing in mind the uncertainty associated with the back trajectory calculations) that either shipping or port activities are a Hg source. Box modelling studies of the summer 2005 campaign show that although the in-situ production of $\mathrm{Hg}_{(\mathrm{g})}^{\mathrm{II}}$ occurs in the MBL, the exact chemical mechanism responsible is difficult to determine. However given the high $\mathrm{O}_{3}$ concentrations encountered during this campaign it seems clear that if $\mathrm{Hg}^{0}$ does react with $\mathrm{O}_{3}$, it does not produce gas phase $\mathrm{Hg}^{\mathrm{II}}$. Equally, the reaction between $\mathrm{Hg}^{0}$ and $\mathrm{OH}$ if it occurs, does not contribute appreciably to $\mathrm{Hg}_{(\mathrm{g})}^{\mathrm{II}}$ production.
\end{abstract}

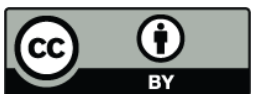

Correspondence to: F. Sprovieri (f.sprovieri@iia.cnr.it)

\section{Introduction}

The world's oceans and seas are the largest emitters of mercury to the atmosphere; industrial emissions account for $2350 \mathrm{Mg} \mathrm{y}^{-1}$, terrestrial emissions $1550 \mathrm{Mg} \mathrm{y}^{-1}$ (excluding biomass burning), whereas ocean emissions contribute roughly $2780 \mathrm{Mg} \mathrm{y}^{-1}$ (Pirrone et al., 2009). Terrestrial emissions and ocean/surface water emissions are sometimes referred to as natural emissions, however, this is slightly misleading. Although a part of the mercury emitted comes from geological and geothermal sources, much of it is recycled $\mathrm{Hg}$ previously emitted from primary or anthropogenic sources, and subsequently redeposited to terrestrial and ocean surfaces (Pirrone et al., 2009; Mason, 2009). The atmosphere is the most important medium by which $\mathrm{Hg}$ is transported around the globe, mostly in the form of elemental Hg. Mercury emitted both from ocean and terrestrial surfaces is elemental mercury $\left(\mathrm{Hg}^{0}\right)$, whereas the majority of $\mathrm{Hg}$ which is deposited (by dry or wet deposition), is oxidised $\mathrm{Hg}\left(\mathrm{Hg}^{\mathrm{II}}\right)$. Most marine waters are saturated in dissolved $\mathrm{Hg}^{0}$, but the precise mechanisms which result in $\mathrm{Hg}^{0}$ emission from marine waters is still unclear. There is evidence that solar radiation enhances emission, either directly, or by its interaction with marine biota, as both abiotic and biotic processes have been suggested as pathways for the reduction of oxidised $\mathrm{Hg}$ to $\mathrm{Hg}^{0}$, (Mason, 2009; Andersson et al., 2007; Fantozzi et al., 2007). The Mediterranean Sea region is particular in numerous ways, it is a unique sea, with a distinct combination of climatological, meteorological, geographical and geological characteristics. It is also rather particular from the point of view of mercury. The area contains $65 \%$ of the world's cinnabar deposits, much of it in a belt that runs from southern Spain to Tuscany in Italy and up into Slovenia. The fact that the Mediterranean is a semi-closed sea bordered by numerous industrialised nations, with a large population living close to the coast, has led to concerns that

Published by Copernicus Publications on behalf of the European Geosciences Union. 
pollutants and contaminants could build up within the Basin and affect wildlife. A number of studies have investigated the concentrations of heavy metals and also persistent organic pollutants (particularly organochlorine and polychlorinated biphenyl compounds, Storelli et al., 2009) in the tissues of marine animals. Mercury has been found in crustaceans, molluscs and fish, but for the most part not at levels which could cause toxic effects in humans (Storelli, 2008). The exception to this generalisation are tuna (albacore and blue fin), and some rays and swordfish, which have been found to contain mercury concentrations above EU and WHO recommendations, especially in larger (older) specimens. A further problem is that the mercury contained in the muscle tissue of fish is almost all methylmercury, which is a potent neurotoxin (Storelli et al., 2005, 2002). The toxicity of methylmercury and its presence in predatory fish is one of the main reasons for $\mathrm{Hg}$ being added to the environmental political agenda in recent years, (European Community, 2001; UNEP, 2008). In many ways the Adriatic Sea is a microcosm of the Mediterranean Sea, with a range of geographical complexities and anthropogenic pressures. For example, to the north of the Adriatic, the Soča/Isonzo river runs past the now disused Idrija mercury mine (Slovenia) and into the Gulf of Trieste (Covelli et al., 2001; Faganeli et al., 2003); there is a major industrial area based around the port of Marghera (Italy); the Bay of Kaštela (Split, Croatia) has been contaminated in the past by a chlor-alkali plant, the repercussions of which continue up to this day (Kljakovic-Gaspic et al., 2006). The coastal zone is densely populated, much of the area is a national and international tourist destination, and there are important fishing and shellfish industries.

Two research cruises to study $\mathrm{Hg}$ in the atmosphere and in sea water were performed in the Adriatic as part of the ongoing Med-Oceanor series of projects. The first in the autumn of 2004 and the second in the summer of 2005. Elemental Hg, Reactive Gaseous Mercury (RGM, the term commonly used to refer to $\left.\mathrm{Hg}_{(\mathrm{g})}^{\mathrm{II}}\right)$ and $\mathrm{Hg}$ associated with particulate matter below $2.5 \mu \mathrm{m},\left(\mathrm{Hg}^{\mathrm{P}}\right)$ were measured continuously during the cruises. The provenance of RGM in the Marine Boundary Layer (MBL) is of much interest as it is readily deposited and therefore plays an important role in the Hg biogeochemical cycle. The concentration of RGM in the Mediterranean MBL has been observed to vary diurnally (particularly in clear weather) peaking around midday or soon after (Sprovieri et al., 2003; Hedgecock et al., 2003, 2005). While it is possible to attribute observed RGM concentrations to in-situ production in the remote MBL (Laurier et al., 2003), the situation in the Mediterranean (and particularly the Adriatic) is not so clear cut. There is the possibility that RGM originates from anthropogenic sources, or that the observed variation in RGM concentration is the result of the change in boundary layer height from night to day, as has been suggested in the case of measurements at coastal sites in the Mediterranean (Wängberg et al., 2008). Instances of high RGM concentrations during the cruises have been investigated using back trajectory analysis using HYSPLIT (Draxler and Rolph, 2003) and the AMCOTS box model (Hedgecock and Pirrone, 2004; Hedgecock et al., 2005). The AMCOTS model has been used previously to simulate the daily variation seen in RGM concentration over the Mediterranean during the summer (Hedgecock et al., 2005). The stability of the atmospheric conditions and general lack of cloud are conducive to the use of a box model, which when constrained by measured $\mathrm{O}_{3}$, humidity, temperature and $\mathrm{Hg}^{0}$ concentration, allow the investigation of the formation of RGM resulting from in-situ oxidation. AMCOTS has also been used in conjunction with measurement data from the Arctic during Hg depletion events (Hedgecock et al., 2008). In this latter case the focus was slightly different, as the study sought to examine if, in the absence of $\mathrm{O}_{3}$ and $\mathrm{OH}$ $\left(\mathrm{O}_{3}\right.$ is depleted contemporaneously with $\left.\mathrm{Hg}^{0}\right)$, the current understanding of $\mathrm{Hg}^{0}+$ halogen oxidation chemistry could account for the rapidity of the diminution of the $\mathrm{Hg}^{0}$ concentration. This study combines both these approaches, the model is used to simulate the in-situ production of RGM and the results compared with measurements. This is aided by the previous identification of possible sources of anthropogenic emissions, where it is to be expected that the model does not accurately reproduce the RGM concentration. The research campaign during the summer of 2005 also allows the investigation of the role of $\mathrm{O}_{3}$ and $\mathrm{OH}$ oxidation of $\mathrm{Hg}^{0}$ in RGM production, because of the continually high $\mathrm{O}_{3}$ mixing ratio encountered throughout the measurement period. The average (day and night) $\mathrm{O}_{3}$ mixing ratio for the period 1429 June was $60 \mathrm{ppb}$, with a maximum of just over $100 \mathrm{ppb}$. The high temperatures (the average over the cruise period was just above $30^{\circ} \mathrm{C}$ ) also means that the thermal decomposition of $\mathrm{Hg}$ addition products which has been proposed (Goodsite et al., 2004) is rapid, further putting the model mechanism to the test. The summer oceanographic campaign therefore serves as a laboratory to test hypotheses about the rate and possible products of reactions between $\mathrm{Hg}^{0}$ and $\mathrm{O}_{3}$, and also $\mathrm{OH}$.

\section{Measurements aboard the R. V. Urania}

Measurements of atmospheric mercury species were conducted across the Adriatic sea aboard the R. V. Urania of the Italian CNR, during two oceanographic campaigns performed along the same route during two seasons, autumn (26 October to 15 November) 2004 and summer (15 June to 5 July) 2005. The campaigns aimed to assess how mercury species concentrations and distribution in the Adriatic MBL change with season and meteorological patterns. The cruise paths of the Med-Oceanor campaigns to date are shown in Fig. 1. The 2004 and 2005 cruise paths (solid and dotted white lines) were identical in the Adriatic, but the 2005 cruise started from Rome and finished at Messina. Collection and 
analysis of $\mathrm{Hg}^{0}, \mathrm{Hg}_{(\mathrm{g})}^{\mathrm{II}}$ and $\mathrm{Hg}^{\mathrm{P}}$ was performed using an automated Tekran (Toronto, Canada) Model 2537A CVAFS, Tekran Model 1130 speciation unit, and Tekran Model 1135 $\mathrm{Hg}^{\mathrm{P}}$ system (Landis et al., 2002). The integrated mercury system was mounted on the top deck of the R. V. Urania with the inlet at about $10 \mathrm{~m}$ above the sea surface. $\mathrm{Hg}^{0}$ samples ( $5 \mathrm{~min}$ ) were continuously quantified by the $2537 \mathrm{~A}$ analyser. The technique is based on amalgamation on two Autraps within the analyser working alternately, and mercury detection by CVAFS. The integrated Tekran speciation system was configured to collect $2 \mathrm{~h} \mathrm{Hg}_{(\mathrm{g})}^{\mathrm{II}}$ and $\mathrm{Hg}^{\mathrm{P}}$ samples on a quartz $\mathrm{KCl}-$ coated annular denuder and quartz filter assembly, respectively. Particles larger than $2.5 \mu \mathrm{m}$ are removed from the air stream by a cyclone before entering the denuder, and smaller particles pass through without deposition on the reactive inner surface under the proper flow rate conditions $\left(101 \mathrm{~min}^{-1}\right)$. After the $2 \mathrm{~h}$ sampling period, a one hour analysis procedure begins by flushing the 1130 and 1135 systems with mercury free air. The $\mathrm{Hg}^{\mathrm{P}}$ and $\mathrm{Hg}_{(\mathrm{g})}^{\mathrm{II}}$ collected on the quartz filter and annular denuder, respectively, were thermally decomposed (at 800 and $500^{\circ} \mathrm{C}$ respectively) into the mercury free air stream and detected as $\mathrm{Hg}^{0}$. During the campaign denuders were re-coated and replaced weekly. The Tekran 2537A analysers were calibrated on a daily basis using the internal permeation tubes. The permeation tube in each of the Tekran 2537A instruments was calibrated just prior to the study as described in Landis et al. (2002) using a Tekran model 2505 primary calibration unit. The detection limit for $\mathrm{Hg}_{(\mathrm{g})}^{\mathrm{II}}$ and $\mathrm{Hg}^{\mathrm{P}}$ under the operating conditions used was less than $2 \mathrm{pg} \mathrm{m}^{-3}$.

\section{Modelling}

\subsection{The AMCOTS photochemical box model}

The AMCOTS (Atmospheric Chemistry Model Over The Sea) model was developed to investigate the atmospheric chemistry of $\mathrm{Hg}$ in the gas and deliquesced aerosol phases in the MBL (Hedgecock et al., 2005). It contains a detailed mechanism to describe gas phase chemistry, photolysis, aqueous phase chemistry in deliquesced sea salt and nonsea salt sulphate aerosol, and the transfer of chemical species between the phases. Originally based on the MOCCA model (Sander and Crutzen, 1996) it has been updated according to the MECCA reaction mechanism (Sander et al., 2005). The Hg chemistry included in the model is similar to that described in (Hedgecock et al., 2005), but in this study a number of possible mechanisms have been investigated, due to the different reaction rate determinations for some $\mathrm{Hg}$ reactions available in the literature. Rate constants determined in the laboratory and also using theoretical techniques have been considered, see Sect. 4.3. The model is used to simulate the concentration of RGM, a catch-all term used to describe the gas phase oxidised $\mathrm{Hg}$ component collected on

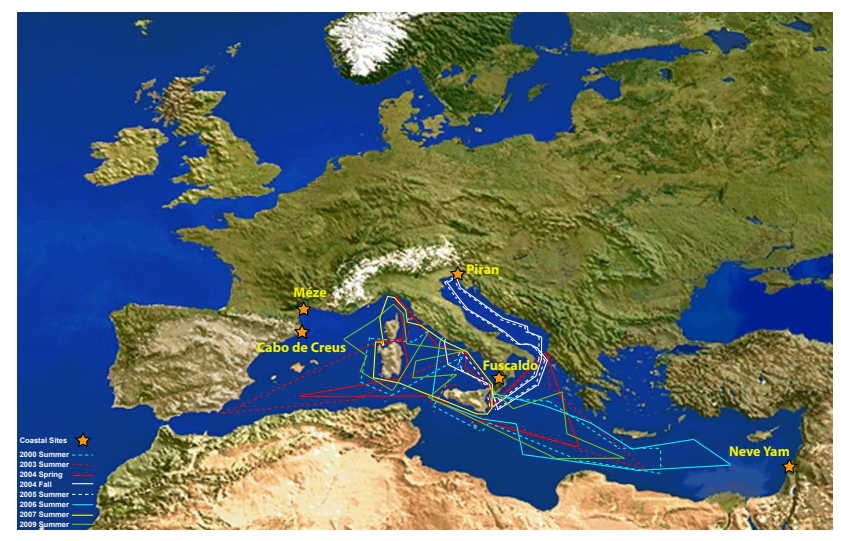

Fig. 1. The routes taken by the R. V. Urania during the MedOceanor oceanographic campaigns. The Adriatic campaign of autumn 2004 and summer 2005 are in white.

the KCl-coated denuders described above in Sect. 2 (Landis et al., 2002). The model is constrained by measurement data, specifically $\mathrm{Hg}^{0}$ and $\mathrm{O}_{3}$ concentration, relative humidity, temperature, as well as latitude and longitude, (for the calculation of photolysis rate constants using Fast-J; Wild et al., 2000). The model concentrations of $\mathrm{O}_{3}, \mathrm{Hg}^{0}$ and water vapour as well as the temperature, latitude and longitude, are updated every five minutes from an input file containing the measurement data. The solar zenith angle angle and photolysis rate constants are recalculated every five minutes; a clear sky was assumed (during the measurement campaign there was fine weather almost all the time). The model reaction mechanism is prepared using KPP (the Kinetic PreProcessor; Damian et al., 2002; Sandu et al., 2003; Daescu et al., 2003) which allows the chemical mechanism to be defined by the user, the inclusion of customised reaction rate constant expressions, and a choice of integration methods. The aerosol loading in the model is considered to be constant and the two classes of aerosol are assumed to have a uniform composition. The aerosol composition is "refreshed" to reflect the deposition of previously emitted particles and the emission of fresh ones, at a rate depending on the typical particle size. The non-sea salt sulphate is completely replaced over a period of 7 days, while the sea salt aerosol, which in our previous studies (Hedgecock and Pirrone, 2004; Hedgecock et al., 2005) was assumed to be replaced over 3 days, is now refreshed more rapidly in light of the recent studies by Lowe et al. (2009), and is assumed to be replaced in 1 day. The model is initiated with typical MBL concentrations in the gas and aqueous phase as described in Sander and Crutzen (1996). The model sensitivity to aerosol loading (specifically the sea salt aerosol fraction) has been discussed in a previous article (Hedgecock and Pirrone, 2004). It was found that increasing the sea salt aerosol loading up to a certain point increases halogen release to the atmosphere, the same effect is found on reducing the replacement time of the 
aerosol. The effect is not great however, doubling the sea salt liquid water content in the model increases the total $\mathrm{Hg}^{0}$ oxidation by approximately $20 \%$ over a week's simulation, while a reduction of the liquid water content by one third decreases the overall oxidation by approximately $30 \%$. Increasing the rate of aerosol replacement also increases the rate of halogen release up to a certain point, however it should be noted that the rate of halogen release is also dependent on the availability of acidic gases which neutralise and then acidify the freshly produced (alkaline) sea salt aerosol. The system therefore does not give simple linear responses in terms of chemical species concentrations to changes in either aerosol loading or replacement time. The sea salt aerosol composition is determined by the average composition of sea water and the equilibration of the droplets water content with the ambient relative humidity. The non-sea salt sulphate aerosol compostion is taken from MECCA (Sander et al., 2005).

\subsection{Back trajectory modelling}

The NOAA Hybrid single-particle Lagrangian integrated trajectory model (HYSPLIT) (Draxler and Rolph, 2003) was used to calculate $72 \mathrm{~h}$ backward trajectories for the R. V. Urania's position at midday and midnight during both oceanographic campaigns. Where there was the suspicion that the ship was in the path of an airmass which had passed nearby a probable $\mathrm{Hg}$ emission source, further trajectories at one hour intervals were calculated. The calculations were performed using the READY website (Rolph, 2003) making use of the archived FNL meteorological datasets.

\section{Results and discussion}

\subsection{Overview of the campaigns}

The average $\mathrm{Hg}^{0}$ concentrations measured during the campaigns were 1.6 and $2.0 \mathrm{ng} \mathrm{m}^{-3}$ for the autumn (2004) and summer (2005) cruises respectively. These values are close to the northern hemispheric background of $1.72 \mathrm{ng} \mathrm{m}^{-3}$ (as measured at Mace Head, Ireland (Kock et al., 2005). They also confirm previous measurements in the Mediterranean Basin which show, that unlike the seasonal variation in $\mathrm{Hg}^{0}$ concentrations observed at Mace Head - higher values in the winter compared to the summer - in the Mediterranean this seasonal variation is the reverse with higher values seen during the summer, (Wängberg et al., 2008). Previous cruises during the summer also show $\mathrm{Hg}^{0}$ concentrations higher than the hemispheric background, $\mathrm{Hg}^{0}$ average of $1.9 \mathrm{ng} \mathrm{m}^{-3}$ in 2000 (Sprovieri et al., 2003), and $1.96 \mathrm{ng} \mathrm{m}^{-3}$ in 2003 (Sprovieri and Pirrone, 2008). During a spring campaign in 2004 average $\mathrm{Hg}^{0}$ concentrations closer to the hemispheric background were observed, $1.75 \mathrm{ng} \mathrm{m}^{-3}$, (Sprovieri and Pirrone, 2008). The reasons for this difference are most likely to be due to the prevailing meteorological conditions during the Mediterranean summer when a stable high pressure system persists over the Basin. This results in a low MBL (around $400 \mathrm{~m}$ ) and air from northern and central Europe flows southward into the region. This southerly motion of air in the boundary layer is responsible for the high $\mathrm{O}_{3}$ concentrations observed across the Mediterranean during summertime (Lelieveld et al., 2002), and also carries anthropogenic $\mathrm{Hg}$ into the MBL. The stability of the summer anticyclone may also result in marine emissions of $\mathrm{Hg}^{0}$ remaining trapped in the MBL and contributing to the higher observed $\mathrm{Hg}^{0}$ concentrations with respect to Mace Head, as has been suggested by (Wängberg et al., 2008). During the measurement campaigns there were a number of occasions in which the concentrations of one or more of $\mathrm{Hg}$ species increased noticeably beyond their average campaign values. These events are summarised in Table 1, where the high concentration event duration and maximum $\mathrm{Hg}$ species concentrations are shown. The table also includes the campaign average concentrations of the $\mathrm{Hg}$ species for comparison. There are three occasions during the autumn cruise when distinct peaks in the $\mathrm{Hg}^{0}$ concentration in combination with either $\mathrm{Hg}^{\mathrm{II}}$ and $\mathrm{Hg}^{\mathrm{P}}$, or both, are seen, as shown in Fig. 2, and in Table 1. The relatively rough sea conditions, combined with the windy and cloudy meteorological conditions during this cruise, make the in-situ oxidation of $\mathrm{Hg}^{0}$ producing observable peaks in the RGM concentration unlikely. The most obvious difference between the measurements made during the autumn and those during the summer cruise is the much greater variation in RGM concentrations, with numerous peaks observed, whereas the $\mathrm{Hg}^{\mathrm{P}}$ concentration showed little variation. There were two major $\mathrm{Hg}^{0}$ peaks and several smaller spikes, which unlike those seen during the autumn campaign, were not always accompanied by peaks in RGM or $\mathrm{Hg}^{\mathrm{P}}$, see Fig. 3 and Table 1 . The origin of these differences between the two cruises has been investigated using back trajectory simulations and also, in the case of the summer cruise, the AMCOTS box model (Hedgecock and Pirrone, 2004; Hedgecock et al., 2005) to simulate local gas and aerosol phase chemistry which could lead to in-situ production of RGM.

\subsection{High Hg species concentration events}

There were four clear high $\mathrm{Hg}$ species concentration events observed during the autumn 2004 measurement campaign, Fig. 2, and three events during the summer which stand out. As mentioned above the observed variation in RGM is very different during the summer compared to the autumn. Apart from a few exceptions, the RGM concentration peaks each day between noon and early afternoon. Similar diurnal variation in RGM has been observed previously in the MBL, both in the Mediterranean (Sprovieri et al., 2003; Hedgecock et al., 2005) and in the Pacific (Laurier et al., 2003). In both cases there was an absence of potential anthropogenic sources suggesting that RGM was being formed by the oxidation of $\mathrm{Hg}^{0}$ within the MBL itself. The generally calm sea conditions and stable atmospheric conditions, with no rain, 
Table 1. The high $\mathrm{Hg}$ species concentration events.

\begin{tabular}{ccccc}
\hline Event Start & Finish & $\mathrm{Hg}^{0} \mathrm{ng} \mathrm{m}^{-3}$ & $\mathrm{Hg}^{\mathrm{II}} \mathrm{pg} \mathrm{m}^{-3}$ & $\mathrm{Hg}^{\mathrm{P}} \mathrm{pg} \mathrm{m}^{-3}$ \\
\hline 28/10/04 12:35 & 29/10/04 17:20 & 2.5 & 62.9 & 17.0 \\
02/11/04 08:25 & $03 / 11 / 0411: 25$ & 2.8 & 5.9 & 15.7 \\
04/11/04 14:50 & $05 / 11 / 0417: 50$ & 3.3 & 4.8 & 50.9 \\
\hline autumn period average & & 1.6 & 4.5 & 6.7 \\
\hline 18/06/05 06:00 & $18 / 06 / 0515: 00$ & 2.1 & 39.9 & 5.4 \\
21/06/05 19:25 & $22 / 06 / 0506: 15$ & 1.7 & 20.9 & 6.8 \\
25/06/05 02:40 (peak) & $25 / 06 / 0517: 40$ & 4.6 & 21.5 & 7.7 \\
26/06/05 08:40 & $26 / 06 / 0516: 35$ & 4.0 & 38.9 & 2.8 \\
\hline summer period average & & 2.0 & 8.1 & 2.8 \\
\hline
\end{tabular}

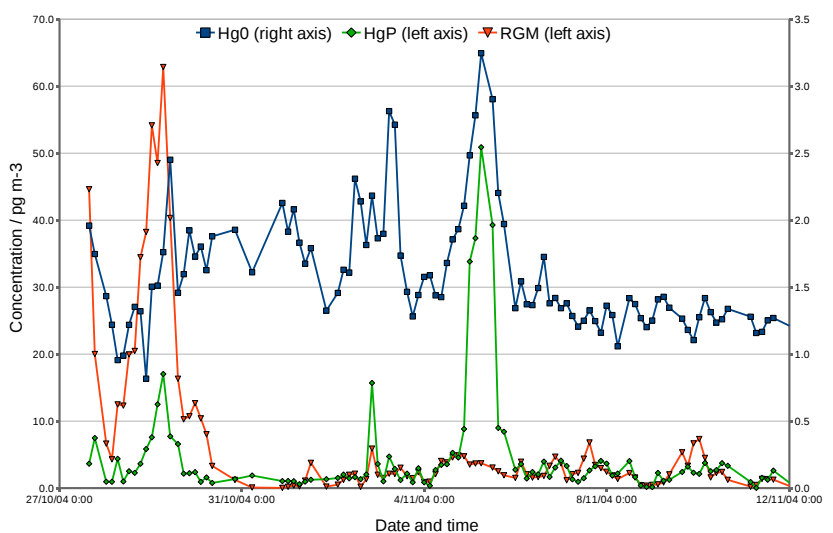

Fig. 2. The measured atmospheric $\mathrm{Hg}$ species concentrations during the summer 2004 oceanographic campaign.

permit the constrained version of the AMCOTS model to be used in an attempt to simulate the daily production of RGM in the MBL. However some anthropogenic plumes clearly were encountered during this campaign, high RGM during night time is an obvious indicator, and back trajectory calculations have again been used to try to identify possible sources.

\subsubsection{8/29 October 2004}

During 27 October and the early hours of 28 October the the $72 \mathrm{~h}$ back trajectories show that the air sampled on board the R. V. Urania originated over the Iberian Peninsula and crosses the sea to the ship, and concentrations of $\mathrm{Hg}$ species are close to the campaign averages. From midday on 28 October the wind still originates from the Iberian Peninsula but passes south of Sicily before changing direction and crossing the island before reaching the ship, as can be seen in Fig. 4a. As the day progresses, the point at which the air masses cross Sicily moves from the western to the eastern end, until at 20:00 h on 28 October the air reaching the R. V. Urania has

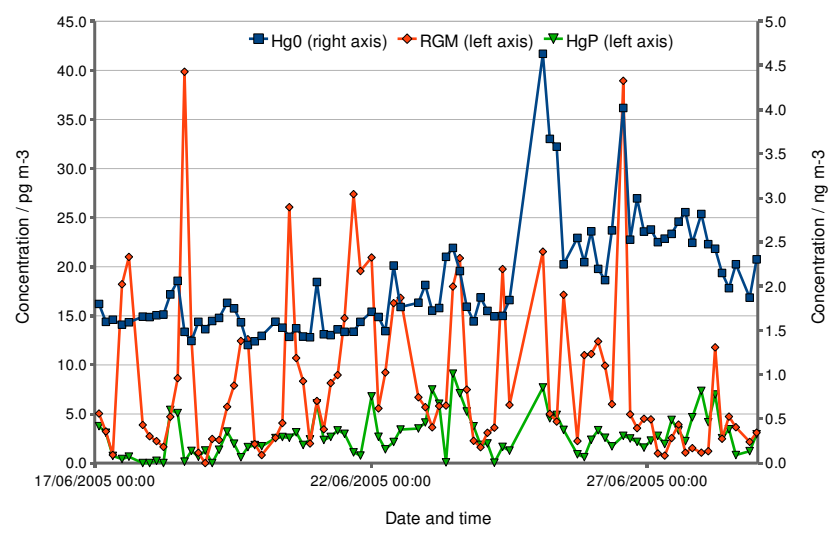

Fig. 3. The measured atmospheric $\mathrm{Hg}$ species concentrations during the autumn 2005 oceanographic campaign.

passed directly over the large industrial and port area around Priolo, Mellili and Augusta, between Catania and Syracuse on the eastern Sicilian coast, as illustrated in Fig. 4b. The concentrations of $\mathrm{Hg}^{0}, \mathrm{RGM}$ and $\mathrm{Hg}^{\mathrm{P}}$ all start to increase The air arriving at the ship continues to come from the same direction for a number of hours and the maximum RGM concentrations are seen in the early hours of the morning of 29 October. The back trajectory calculations suggest that the airmass has travelled for roughly six hours before being sampled, and thus the emission of $\mathrm{Hg}^{0} / \mathrm{RGM} / \mathrm{Hg}^{\mathrm{P}}$ occurred during the hours of darkness, and the RGM peak is therefore clearly not the result of $\mathrm{Hg}$ oxidation resulting from MBL photochemistry. By midday on 29 October the wind is coming more from the south-east than the south and so crosses just a small part of the north-east corner of Sicily before arriving at the Urania, and this is reflected by a decrease in the observed RGM. Interestingly the next day the ship passes very close to the Priolo-Augusta area, but with winds from the south-east, no noticeable increase in any of the $\mathrm{Hg}$ species was observed. There is the possibility that the observed $\mathrm{Hg}^{0} / \mathrm{RGM} / \mathrm{Hg}^{\mathrm{P}}$ are the result of emissions from 

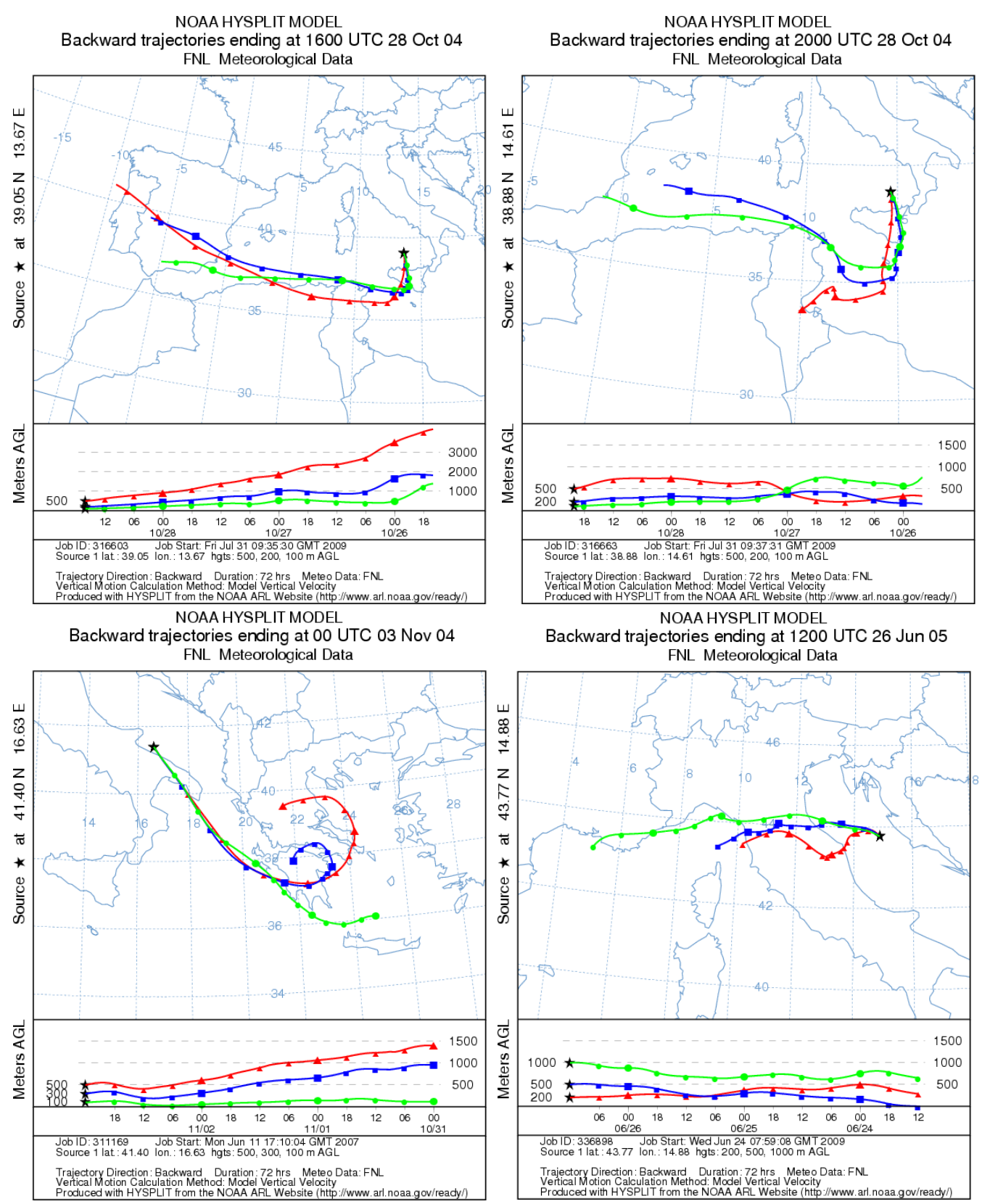

Fig. 4. Some of the back trajectories calculated using HYSPLIT (Draxler and Rolph, 2003; Rolph, 2003).

Mount Etna. Bagnato et al. (2007) observed all three atmospheric $\mathrm{Hg}$ species outgassing from vents in Mount Etna. Given the altitude of the vents (over $3000 \mathrm{~m}$ (Bagnato et al., 2007) and the stability of the MBL during summertime anticyclonic conditions, it appears unlikely that these emissions were observed on the R. V. Urania, but the possibility does need to be investigated using regional scale chemistry and transport models.

\subsubsection{November 2004}

A peak in both $\mathrm{Hg}^{0}$ and $\mathrm{Hg}^{\mathrm{P}}$ were observed as well as a small but distinct increase in RGM on the night between 2 and 3 November. The Urania was in the Adriatic off the coast from Bari, and the air mass arriving at the ship had passed over the open Mediterranean and then into the Ionian Sea, between Puglia and Calabria. After this it passed overland between Taranto and Bari, the airmass reached the R. V. Urania just over six hours later, as shown in Fig. 4c. The largest iron and steel foundry in Europe is located in the industrial 
zone to the north-west of the town of Taranto and has been the subject of a written question in the European Parliament as recently as 2008 regarding its emissions. After passing Taranto the airmass passed overland without change in altitude until reaching the Adriatic. The relative lack of RGM may be due to the nature of the emissions from the industrial area or the result of the more rapid deposition of RGM compared to $\mathrm{Hg}^{\mathrm{P}}$.

\subsubsection{November 2004}

Marked peaks in $\mathrm{Hg}^{0}$ and $\mathrm{Hg}^{\mathrm{P}}$ were observed, but not in RGM. The back trajectories suggest that the air sampled on the Urania had crossed the Balkans at low altitude encountering hilly and forested terrain. In the previous $72 \mathrm{~h}$ the airmass sampled has crossed part of Bulgaria, Serbia, Bosnia and Herzegovina, and finally Croatia. The source or sources of the observed peaks in $\mathrm{Hg}^{0}$ and $\mathrm{Hg}^{\mathrm{P}}$ is not so obvious in this instance. However, $12 \mathrm{~h}$ prior to sampling, the airmass passed close to Rijeka, the largest seaport in Croatia, and given the rapidity with which RGM deposits, it is possible that, in part at least, the elevated $\mathrm{Hg}^{\mathrm{P}}$ may well have originated from the port area.

\subsubsection{June 2005}

There is an increase in $\mathrm{Hg}^{\mathrm{P}}$ between 06:00 and 12:00 accompanied by an increase in $\mathrm{Hg}^{0}$. RGM increases slowly until midday and then increases more rapidly peaking at 15:00, and then has decreased again by the next analysis time at 18:00. The air mass being sampled had crossed the southern Adriatic before crossing Puglia, the Ionian Sea and then Calabria before skirting Gioia Tauro ( $12 \mathrm{~h}$ before sampling), and crossing the extreme southern tip of Calabria before reaching the ship off the east coast of Sicily. Gioia Tauro is the largest container port in the Mediterranean. It is possible that this event is caused by emissions from the port area, followed by RGM deposition as the air crosses the hilly southern tip of Calabria, and that the later peak in RGM is due in part to the oxidation of $\mathrm{Hg}^{0}$ in the $6 \mathrm{~h}$ spent in the MBL (low wind) before the air reaches the Urania. This possibility is discussed again in Sect. 4.4 below.

\subsubsection{1/22 June 2005}

During the afternoon of 21 June the RGM concentration begins to decrease and then picks up again from about 18:00 onwards and reaches a maximum at midnight, after which it decreases again. The $\mathrm{Hg}^{\mathrm{P}}$ concentration also increases rising above $5 \mathrm{pg} \mathrm{m}^{-3}$. During the late afternoon the air arriving at the R. V. Urania has come south-west across the Adriatic from the Split/Kaštela area of Croatia, approximately $18 \mathrm{~h}$ earlier. As the evening goes on, the airmass, particularly the lower trajectories calculated (100 and $500 \mathrm{~m}$ ) continues to come from the Croatian coast but crosses it progressively further to the north as the night goes on. By 03:00 in the morn- ing of 22 June the air is crossing over the sea to the north of Šibenik. The area of Kaštela has an aluminium smelter and had a mercury-cell chlor-alkali plant, as mentioned before in the Introduction, and Split is a major port.

\subsubsection{June 2005}

At 02:40 in the morning the $\mathrm{Hg}^{0}$ and RGM increase, this is most likely an airmass which has been influenced by anthropogenic emissions, as RGM production during the hours of darkness is much slower than during the day. Interestingly the R. V. Urania was in the Gulf of Trieste at this point, and the air mass had recently passed close to the port of Rijeka in Croatia, and also the shipping lanes leading out of the bay, where the port is situated, into the open Adriatic.

\subsubsection{June 2005}

The $\mathrm{Hg}^{0}$ concentration begins to increase from about 08:00. An examination of the hourly back trajectories shows that they do not change significantly between 06:00 and 17:00. The increase in $\mathrm{Hg}^{0}$ is accompanied by an increase in RGM but not $\mathrm{Hg}^{\mathrm{P}}$. The back trajectories show that the air being sampled aboard the R. V. Urania has crossed the Italian peninsula from the northern Tyrrhenian Sea and that it has passed by Ancona, a major Adriatic port, see Fig. 4d. The air arriving at the position of the R. V. Urania has been over the sea for more than $12 \mathrm{~h}$, so in this instance it seems plausible that the observed RGM is the result of both a local emission and in-situ oxidation of $\mathrm{Hg}^{0}$, this possibility is discussed further in Sect. 4.4 below.

\subsection{Box modelling studies}

The box model has been used with the concentrations of $\mathrm{Hg}$ and $\mathrm{O}_{3}$ constrained by measurements. $\mathrm{OH}$ is also effectively constrained by the measured $\mathrm{O}_{3}$ concentration and relative humidity. Using typical values to describe the sea salt and non-sea salt sulphate aerosol, the calculated concentration of $\mathrm{Hg}_{\mathrm{g}}^{\mathrm{II}}$ has been compared to the values measured during the summer 2005 campaign. A number of different combinations of reactions and reaction rate constants for the oxidation of elemental $\mathrm{Hg}$ were tried, as there is some uncertainty as to the atmospheric $\mathrm{Hg}$ oxidation mechanism, (Hynes et al., 2009; Ariya et al., 2009). There have been both laboratory measurements and theoretical calculations of the reaction rate constants for $\mathrm{Hg}$ with halogen atoms and molecules, and for the reactions with $\mathrm{O}_{3}$ and $\mathrm{OH}$. The uncertainty mentioned above mostly centres around the stability of possible excited intermediates such as $\mathrm{HgBr}^{*}$ and $\mathrm{HgOH}^{*}$, and whether the $\mathrm{Hg}^{0}+\mathrm{O}_{3}$ (and $\mathrm{Hg}^{0}+\mathrm{OH}$ ) reactions occur at appreciable rates. The physical state of possible reaction products is another difficulty, especially given that the experimental technique used to sample and quantify $\mathrm{Hg}_{\mathrm{g}}^{\mathrm{II}}$ in the field, relies on thermally decomposing the compounds collected and detecting $\mathrm{Hg}$ as $\mathrm{Hg}^{0}$. The box model has therefore been used with a 


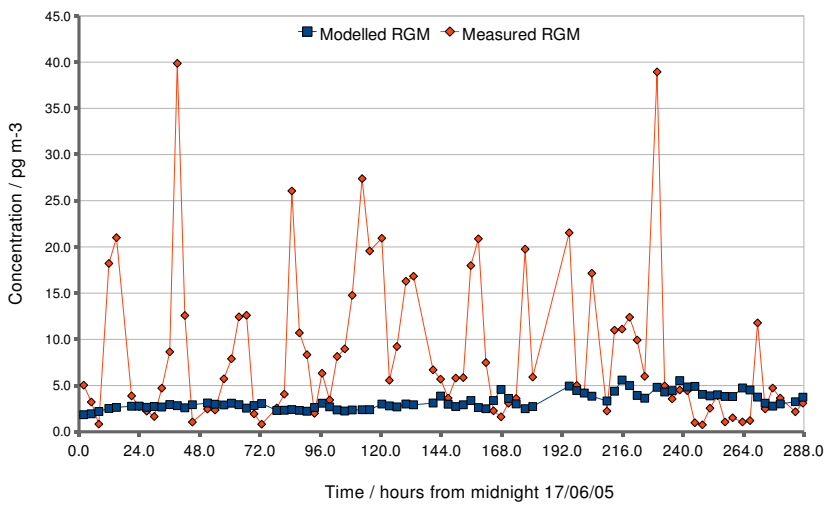

Fig. 5. The measured and modelled RGM concentration, assuming all reaction products contribute to RGM and using the $\mathrm{Hg}^{0}+\mathrm{O}_{3}$ reaction rate constant from Hall (1995).

large number of slightly different reaction rate mechanisms, in which combinations of the following possibilities were used;

$\mathrm{Hg}^{0}+\mathrm{O}_{3} \rightarrow \mathrm{Hg}_{(\mathrm{g})}^{\mathrm{II}}, k=3.0 \times 10^{-20} \mathrm{~cm}^{3}$ molecules ${ }^{-1} \mathrm{~s}^{-1}$

(Hall, 1995) or

$k=8.43 \times 10^{-17} \exp (-11700 / R T) \mathrm{cm}^{3}$ molecules $^{-1} \mathrm{~s}^{-1}$

(Pal and Ariya, 2004)

$\mathrm{Hg}^{0}+\mathrm{OH} \rightarrow \mathrm{Hg}_{(\mathrm{g})}^{\mathrm{II}}$,

$k=3.55 \times 10^{-14} \exp (-2440 / R T) \mathrm{cm}^{3}$ molecules ${ }^{-1} \mathrm{~s}^{-1}$,

(Pal and Ariya, 2004) or

$\mathrm{Hg}^{0}+\mathrm{OH} \leftrightarrow \mathrm{HgOH}^{*}$,

$k=3.2 \times 10^{-13}(T / 298 \mathrm{~K})^{-3.06} \mathrm{~cm}^{3}$ molecules ${ }^{-1} \mathrm{~s}^{-1}$,

forwards

$k=2.7 \times 10^{9} \exp (-4061 / T) \mathrm{s}^{-1}$

backwards, (Goodsite et al., 2004).

$\mathrm{Hg}^{0}+\mathrm{Br} \rightarrow \mathrm{HgBr}$,

$k=1.46 \times 10^{-32}(T / 298)^{-1.86} \mathrm{~cm}^{3}$ molecules $^{-1} \mathrm{~s}^{-1}$,

(Donohoue et al., 2006) or

$k=3.2 \times 10^{12} \mathrm{~cm}^{3}$ molecules ${ }^{-1} \mathrm{~s}^{-1}$,

(Ariya et al., 2002) in this instance assuming that this is the rate limiting step and that $\mathrm{HgBr}$ further reacts rapidly to form an $\mathrm{Hg}^{\mathrm{II}}$ compound in the gas phase.

$\mathrm{Hg}^{0}+\mathrm{Br} \leftrightarrow \mathrm{HgBr}^{*}$,

$k=1.1 \times 10^{-12}(T / 298 \mathrm{~K})^{-2.37} \mathrm{~cm}^{3}$ molecules ${ }^{-1} \mathrm{~s}^{-1}$

forwards and

$k=1.2 \times 10^{10} \exp (-8357 / T) \mathrm{s}^{-1}$

for the reverse reaction (Goodsite et al., 2004), and

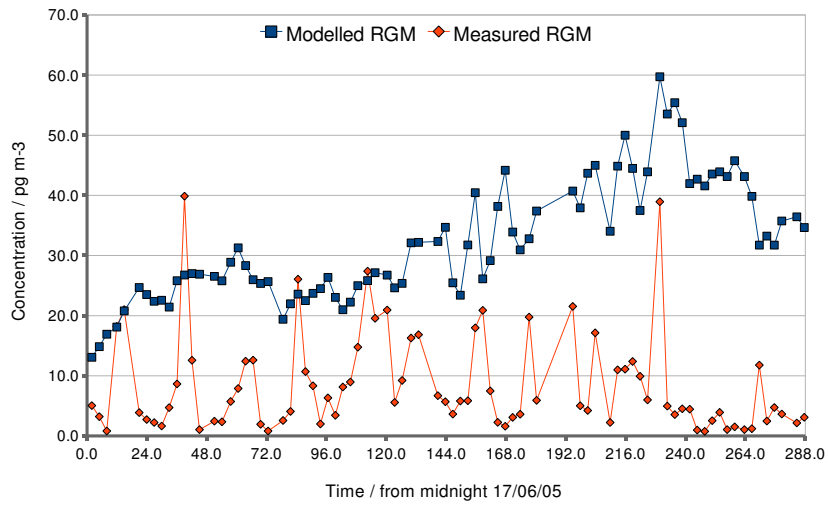

Fig. 6. The measured and modelled RGM concentration, assuming all reaction products contribute to $\mathrm{RGM}$ and using the $\mathrm{Hg}^{0}+\mathrm{O}_{3}$ reaction rate constant from Pal and Ariya (2004).

$\mathrm{HgBr}+\mathrm{Br} \rightarrow \mathrm{HgBr}_{2}$,

$k=22.5 \times 10^{-10}(T / 298 \mathrm{~K})^{-0.57} \mathrm{~cm}^{3}$ molecules ${ }^{-1} \mathrm{~s}^{-1}$

(Goodsite et al., 2004).

The reaction between $\mathrm{Hg}^{0}$ and $\mathrm{BrO}$ (Raofie and Ariya, 2003) was also included in the reaction mechanism but proved to be of little importance when compared to the reactions above. For many of the combinations tried the results were clearly way off the mark, either failing to reproduce the midday maxima (both over and underestimates were obtained), the nocturnal minima (commonly overestimated) or, and this applied to almost all the simulations, failing to reproduce the extent of the diurnal variation. With the $\mathrm{O}_{3}+\mathrm{Hg}^{0}$ rate constant from Hall (1995) and the $\mathrm{HgBr}^{*}$ allowed to decay back to reactants, the RGM minima are in the right ball park but the maxima are far too low. Including the $\mathrm{HgOH}^{*}$ decay gave an almost flat line for the RGM concentration, as shown in Fig. 5. Using the Pal and Ariya (2004) value for $\mathrm{k}\left(\mathrm{Hg}^{0}+\mathrm{O}_{3}\right)$ and both the $\mathrm{HgOH}^{*}$ and $\mathrm{HgBr}^{*}$ formation and decomposition values from Goodsite et al. (2004), continual build up of RGM occurs and very little day to night variation is seen (Fig. 6). The removal of one or both of the excited state decays from the reaction mechanism gives a more realistic profile but the modelled minimum concentration remains significantly too high. Following these tests the products of the $\mathrm{Hg}^{0}+\mathrm{O}_{3}$ and $\mathrm{Hg}^{0}+\mathrm{OH}$ reaction were assumed to be solid and therefore not to contribute to the modelled RGM concentration. At this point it made no difference which rate constant was used for the reactions, as the $\mathrm{Hg}^{0}$ concentration is constrained within the model and updated every time step from the measured data, therefore the rate at which $\mathrm{Hg}^{0}$ is consumed does not influence RGM production from the other gas phase reactions. A previous study (Hedgecock et al., 2005) found that a combination of the Pal and Ariya (2004) rate constant and the assumption of solid products (from $\mathrm{Hg}^{0}+\mathrm{O}_{3}$ and $\mathrm{Hg}^{0}+\mathrm{OH}$ ) gave results comparable 
to those using the $\mathrm{Hg}^{0}+\mathrm{O}_{3}$ rate constant from Hall (1995) but assuming that the reaction products contributed to RGM. For the summer 2005 results modelled concentrations of RGM similar to the observations were obtained only by assuming that the formation of the $\mathrm{HgBr}^{*}$ intermediate is the rate limiting step in the formation of RGM, and using the Ariya et al. (2002) rate coefficient for $\mathrm{Hg}^{0}+\mathrm{Br}$ rather than the rate expression from Donohoue et al. (2006). Figure 7 shows the model results assuming that the $\mathrm{Hg}^{0}+\mathrm{O}_{3}$ and $\mathrm{Hg}^{0}+\mathrm{OH}$ reactions do not give products that contribute to RGM, and that the $\mathrm{HgBr}^{*}$ recombination product is converted to RGM before it can decay back to the initial reactants. Recently high concentrations of $\mathrm{BrO}$ have been observed in a semi-polluted MBL (Mahajan et al., 2009). To assess whether the initial conditions and NO emission rate employed in the model affected the release of brominated compounds to the MBL a number of test studies were performed. It proved possible to increase both the rate and overall amount of $\mathrm{Br}$ compound release from the aerosol by increasing the aerosol loading (higher liquid water content of the sea salt aerosol) and also by assuming the MBL was more polluted (higher $\mathrm{NO}_{2}$ initial concentration and higher NO emission rate). Doubling the sea salt aerosol loading increased $\mathrm{Br}$ and $\mathrm{BrO}$ concentrations by a factor of roughly 1.5 , but this was not sufficient to reproduce the observations if the $\mathrm{HgBr}^{*}$ produced in the $\mathrm{Hg}^{0}+\mathrm{Br}$ reaction was permitted to thermally dissociate back to $\mathrm{Hg}^{0}+\mathrm{Br}$. Increasing the $\mathrm{NO}_{\mathrm{x}}$ concentration in the model so that the average $\mathrm{NO}_{2}$ concentration increased threefold from 40 to $120 \mathrm{ppt}$, increased peak daytime $\mathrm{BrO}$ by $50 \%$. However the greatest change was seen in the nocturnal concentrations of $\mathrm{Cl}_{2}$ (a tenfold increase) and $\mathrm{NO}_{3}$ (also a tenfold increase), which contrived to increase the nocturnal $\mathrm{Hg}^{0}$ oxidation rate, to such an extent, that a small but discernible peak in RGM was seen soon after midnight, contrary to all observations made thus far in the MBL. It has to be concluded therefore that these simulations are unrealistic.

In our sensitivity tests we varied $\mathrm{CO}, \mathrm{NO}_{\mathrm{x}}$ and $\mathrm{VOC}$ input concentrations (and $\mathrm{NO}$ emissions from the sea surface). The $\mathrm{NO}_{\mathrm{x}}$ concentration affects the model results because higher concentrations of oxidised $\mathrm{N}$ compounds increase the rate at which the sea salt aerosol is acidified and therefore promotes the release of reactive halogen compounds to the atmosphere. Using an initial value of $50 \mathrm{ppt}$ of $\mathrm{NO}_{2}$ (compared to $20 \mathrm{ppt}$ ) and an NO emission flux of $5 \times 10^{-9}$ molecules $\mathrm{cm}^{-2} \mathrm{~s}^{-1}$ rather than $1.5 \times 10^{-9}$ molecules $\mathrm{cm}^{-2} \mathrm{~s}^{-1}$ has the result of increasing the model RGM beyond the observed concentrations. If we assume that the reaction between $\mathrm{Hg}^{0}$ and $\mathrm{OH}$ produces oxidised gas phase $\mathrm{Hg}$ compounds, concentrations of $\mathrm{CO}$ above $1000 \mathrm{ppb}$ (to reduce the $\mathrm{OH}$ concentration) are necessary to produce model RGM concentrations similar to those observed. Combining high $\mathrm{NO}_{\mathrm{x}}$ and $\mathrm{CO}$ concentrations gives model results higher than observations. The VOC concentration affects both halogen (Toyota et al., 2004) and $\mathrm{OH}$ concentrations and it is difficult to be precise as to the effect, however the influence on the

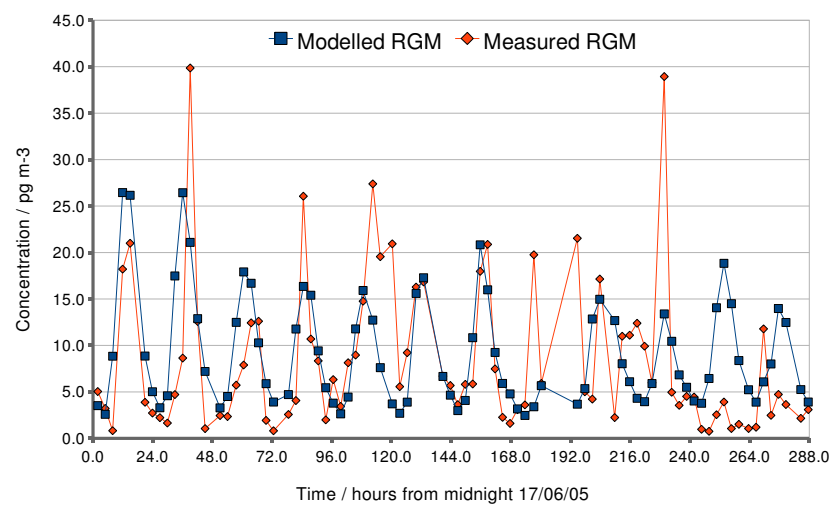

Fig. 7. The measured and modelled RGM concentration, assuming that $\mathrm{Hg}^{0}+\mathrm{O}_{3}$ and $\mathrm{Hg}^{0}+\mathrm{OH}$ reaction products do not contribute to RGM and assuming that $\mathrm{Hg}^{0}+\mathrm{Br}$ is the rate limiting step in RGM formation.

modelling results is small in comparison to $\mathrm{NO}_{\mathrm{x}}$ or $\mathrm{CO}$ if the $\mathrm{Hg}^{0}+\mathrm{OH}$ reaction is assumed to give a gaseous product. Under the high $\mathrm{O}_{3}$ conditions encountered, assuming a $\mathrm{CO}$ concentration of $100 \mathrm{ppb}$ gives a maximum $\mathrm{OH}$ concentration of $3.2 \times 10^{7}$ molecules $\mathrm{cm}^{-3}, 200 \mathrm{ppb}$ (the value used in the simulations) a maximum of $2.3 \times 10^{7}$ molecules $\mathrm{cm}^{-3}$ and $300 \mathrm{ppb} \mathrm{CO}$ a maximum of $1.8 \times 10^{7}$ molecules $\mathrm{cm}^{-3}$. As mentioned above if the reaction between $\mathrm{Hg}^{0}$ and $\mathrm{OH}$ is assumed to give a gas phase product it is necessary to increase the CO concentration to around $1000 \mathrm{ppb}$ in order to obtain RGM values similar to observations (using either the temperature dependent $\mathrm{Hg}^{0}+\mathrm{OH}$ rate constant from Pal and Ariya (2004) (Eq. 3), or the temperature independent rate constant from Sommar et al. (2001) of $8.7 \times 10^{-14} \mathrm{~cm}^{3}$ molecules $\left.{ }^{-1} \mathrm{~s}^{-1}\right)$. Measurements made during the MINOS campaign (Berresheim et al., 2003; Salisbury et al., 2003) found CO concentrations between 100 and $200 \mathrm{ppb}$ and $\mathrm{OH}$ concentrations which peaked at around $2.7 \times 10^{7}$ molecules $\mathrm{cm}^{-3}$. We are therefore reasonably confident that the model is reproducing the $\mathrm{OH}$ concentration with a fair degree of accuracy. The chemical mechanism employed for the summer 2005 results was used to re-run the simulations for the summer 2000 oceanographic campaign described in Sprovieri et al. (2003) and modelled in Hedgecock et al. $(2003,2005)$. The comparison between the simulated and observed RGM concentrations proved to be similar to those previously published with the Index of Agreement metric (see Hedgecock et al., 2005) differing by just 0.06 , having a value in this case of 0.63 rather than 0.69 . Thus the mechanism employed for this study which covers only the Adriatic can also reproduce reaasonably the data from the summer 2000 oceanographic campaign which covered a far larger of the Mediterranean. The simulation shown in Fig. 7 has an IOA of 0.67 , with an average modelled RGM concentration of $9.0 \mathrm{pg} \mathrm{m}^{-3}$ compared to the $8.2 \mathrm{pg} \mathrm{m}^{-3}$ observed. 


\subsection{The high mercury species concentration events encountered during the summer campaign}

The four high Hg species events identified in the measurements during the summer 2005 campaign are easily identifiable in Fig. 7. At midday on 18 June the model underestimates the RGM concentration by $15 \mathrm{pg} \mathrm{m}^{-3}$, approximately $35 \%$. As the possible arrival of air influenced by anthropogenic emissions at the position of the Urania is close to the time of the peak concentration of RGM produced insitu, it would be easy to assume that the model had failed to reproduce the observed concentration. This is also true in the case of the event of 26 June where the observed RGM is underestimated by over $60 \%$. Once again, as the probable anthropogenic emission influence on the measurements occurs close to midday, it would be easy to interpret the discrepancy as a failing in the model. The plumes which were detected around midnight of 22 and 25 June are much more simply attributable to an external and not local (in situ) influence. All of these instances clearly reduce the apparent ability of the model to predict RGM concentration from the given $\mathrm{Hg}^{0}$ concentration. The Index of Agreement mentioned in Sect. 4.3 improves by more than $10 \%$ to 0.74 if these outliers are not included. The model can therefore give an insight as to the proportion of the atmospheric RGM loading resulting from in-situ oxidation (including that from the $\mathrm{Hg}^{0}$ emitted by a local source), and that which is transported directly from a possible emission source.

\subsection{Atmospheric mercury cycling over the Adriatic}

The debate over which reactions are important in the atmospheric oxidation of $\mathrm{Hg}$ appears set to continue for some time. Box modelling studies seem to indicate that RGM production in the atmosphere is dominated by reactions involving $\mathrm{Br}$ compounds (Hedgecock et al., 2008; Holmes et al., 2009), while many regional models still rely on $\mathrm{O}_{3}$ and $\mathrm{OH}$ as atmospheric oxidants, and $\mathrm{HO}_{2}$ as a reductant in cloud water (Ryaboshapko et al., 2007a,b). Global modelling studies use a range of chemical mechanisms of varying complexity, and various treatments of deposition and re-emission, or aqueous phase reduction of $\mathrm{Hg}^{\mathrm{II}}$, which allow the hemispheric uniformity of $\mathrm{Hg}^{0}$ concentrations to be reproduced (for example, Jung et al., 2009; Selin et al., 2008; Seigneur et al., 2006; Travnikov, 2005; Dastoor and Larocque, 2004). Holmes et al. (2006) investigated the free tropospheric lifetime of $\mathrm{Hg}$ with respect to oxidation by $\mathrm{Br}$ using the reaction rate coefficients from Goodsite et al. (2004), and more recently used a box model to assess the sources and deposition of RGM in the MBL (Holmes et al., 2009). The authors concluded that it was possible to fit RGM observations without including the oxidation to RGM of $\mathrm{Hg}^{0}$ by $\mathrm{O}_{3}$, if the entrainment flux from the free troposphere was increased in their model. As mentioned in the Introduction, the Adriatic in the summer provides a hot, ozone rich environment to study the production of RGM in the MBL. In fact it proved difficult to reconcile published measured and theoretical rate constants for atmospheric $\mathrm{Hg}^{0}$ oxidation reactions with the observations, and the only way proved to be the assumption that the $\mathrm{Hg}^{0}+\mathrm{O}_{3}$ and $\mathrm{Hg}^{0}+\mathrm{OH}$ reactions do not give products that contribute to RGM. However this does not bring us any closer to knowing whether they do actually occur, and if so what the products are. The other assumption that proved necessary was that the $\mathrm{Hg}^{0}+\mathrm{Br}$ reaction controls the rate at which RGM is produced and that therefore $\mathrm{HgBr}^{*}$ is rapidly converted to RGM. The temperatures encountered during the cruise were such that the thermal dissociation (Goodsite et al., 2004), occurred so rapidly in the model that almost no RGM was produced at all, when it was included in the model reaction mechanism. The observation of high atmospheric $\mathrm{Hg}$ species concentrations, associated with air masses which had recently passed over, or very close to port areas, is of some concern. Further work is needed to distinguish between emissions from ships themselves and those associated with port activity or other local sources. There is currently much interest in ships as sources of pollutants which affect air quality, in part because global shipping is predicted to increase, whilst emissions from other sources are being always more stringently controlled, thus making ship emissions an ever more important source of contaminants. This is particularly true where busy shipping routes run close to population centres, the Mediterranean is a prime example of such a case (Marmer et al., 2009). As far as the authors are aware no mercury emission inventories include shipping among their emission categories.

\section{Conclusions}

The two cruise campaigns in the Adriatic demonstrate the complexity of $\mathrm{Hg}$ cycling in the MBL in general, and the importance of anthropogenic influences particularly in areas not far from the coast. The Adriatic is perhaps more susceptible to these influences than many parts of the Mediterranean or ocean environments, because it is extremely narrow. The back trajectory analyses demonstrate that in the Adriatic it does not really matter in which direction the wind is coming from, a part will be influenced by an anthropogenic emission source due to either regional industries or shipping/port activities or both. There are two important sources of $\mathrm{Hg}$ in the Mediterranean (and other regions) which are generally not included in emission inventories, biomass burning and shipping. While some progress has been made with the biomass burning contribution to the atmospheric $\mathrm{Hg}$ loading, (Cinnirella et al., 2008; Friedli et al., 2009; Wiedinmyer and Friedli, 2007) shipping emissions remain unquantified and as yet unestimated. The consensus of opinion seems to be moving away from considering $\mathrm{O}_{3}$ and $\mathrm{OH}$ the most important atmospheric oxidants of $\mathrm{Hg}^{0}$, to the view that $\mathrm{Br}$ radicals and possibly other $\mathrm{Br}$-containing compounds are the 
more important (see Holmes et al., 2009; Hynes et al., 2009; Ariya et al., 2009). This causes no little concern from a modelling point of view, because although it is possible to include detailed $\mathrm{Br}$ chemistry in box models (Hedgecock et al., 2005, 2008; Holmes et al., 2009), its inclusion in regional and global models presents far greater problems, and as yet has only been done in a parametrised or climatological fashion (Seigneur et al., 2006; Holmes et al., 2006; Dastoor et al., 2008). The difficulty is doubled in this case, as there is uncertainty in the $\mathrm{Hg}$ chemistry, and also a less than complete understanding of the sources and chemistry of Br-containing compounds in the atmosphere, as shown recently by Mahajan et al. (2009). Finally it should be reiterated that the use of the term "RGM" is less than satisfactory; in order to understand the atmospheric cycling of $\mathrm{Hg}$ on any scale between very local and global, it is of the utmost importance to identify the compounds which are collected on $\mathrm{KCl}$-coated denuders, and which make up the oxidised component of atmospheric $\mathrm{Hg}$.

Acknowledgements. The authors gratefully acknowledge the NOAA Air Resources Laboratory (ARL) for the provision of the HYSPLIT transport and dispersion model and/or READY website (http://www.arl.noaa.gov/ready.php) used in this publication.

Edited by: K.-H. Kim

\section{References}

Andersson, M., Gårdfeldt, K., Wängberg, I., Sprovieri, F., Pirrone, N., and Lindqvist, O.: Seasonal and daily variation of mercury evasion at coastal and off shore sites from the Mediterranean Sea, Marine Chem., 104, 214-226, 2007.

Ariya, P. A., Khalizov, A., and Gidas, A.: Reactions of Gaseous Mercury with Atomic and Molecular Halogens: Kinetics, Product Studies, and Atmospheric Implications, The Journal of Physical Chemistry A, 106, 7310-7320, doi:10.1021/jp020719o, 2002.

Ariya, P. A., Peterson, K., Snider, G., and Amyot, M.: Mercury chemical transformations in the gas, aqueous and heterogeneous phases: state-of-the-art science and uncertainties, in: Mercury Fate and Transport in the Global Atmosphere: Emissions, Measurements and Models, edited b:y Pirrone, N. and Mason, R. P., 459-501, Springer, http://dx.doi.org/10.1007/ 978-0-387-93958-2_15, ISBN: 978-0-387-93957-5, 2009.

Bagnato, E., Aiuppa, A., Parello, F., Calabrese, S., D’Alessandro, W., Mather, T., McGonigle, A., Pyle, D., and Wängberg, I.: Degassing of gaseous (elemental and reactive) and particulate mercury from Mount Etna volcano (Southern Italy), Atmos. Environ., 41, 7377-7388, doi:doi:10.1016/j.atmosenv.2007.05.060, 2007.

Berresheim, H., Plass-Dülmer, C., Elste, T., Mihalopoulos, N., and Rohrer, F.: $\mathrm{OH}$ in the coastal boundary layer of Crete during MINOS: Measurements and relationship with ozone photolysis, Atmos. Chem. Phys., 3, 639-649, 2003, http://www.atmos-chem-phys.net/3/639/2003/.

Cinnirella, S., Pirrone, N., Allegrini, A., and Guglietta, D.: Modeling mercury emissions from forest fires in the Mediterranean re- gion, Environmental Fluid Mechanics, 8, 129-145, doi:10.1007/ s10652-007-9048-1, 2008.

Covelli, S., Faganeli, J., Horvat, M., and Brambati, A.: Mercury contamination of coastal sediments as the result of long-term cinnabar mining activity (Gulf of Trieste, northern Adriatic sea), Appl. Geochem., 16, 541-558, doi:10.1016/S0883-2927(00) 00042-1, 2001.

Daescu, D. N., Sandu, A., and Carmichael, G. R.: Direct and adjoint sensitivity analysis of chemical kinetic systems with KPP: II-numerical validation and applications, Atmos. Environ., 37, 5097-5114, doi:10.1016/j.atmosenv.2003.08.020, 2003.

Damian, V., Sandu, A., Damian, M., Potra, F., and Carmichael, G. R.: The kinetic preprocessor KPP-a software environment for solving chemical kinetics, Computers \& Chemical Engineering, 26, 1567-1579, doi:10.1016/S0098-1354(02)00128-X, 2002.

Dastoor, A. P. and Larocque, Y.: Global circulation of atmospheric mercury: a modelling study, Atmos. Environ., 38, 147-161, doi: 10.1016/j.atmosenv.2003.08.037, 2004.

Dastoor, A. P., Davignon, D., Theys, N., Van Roozendael, M., Steffen, A., and Ariya, P. A.: Modeling Dynamic Exchange of Gaseous Elemental Mercury at Polar Sunrise, Environ. Sci. Technol., 42, 5183-5188, http://dx.doi.org/10.1021/es800291w, 2008.

Donohoue, D. L., Bauer, D., Cossairt, B., and Hynes, A. J.: Temperature and Pressure Dependent Rate Coefficients for the Reaction of $\mathrm{Hg}$ with $\mathrm{Br}$ and the Reaction of $\mathrm{Br}$ with $\mathrm{Br}$ : A Pulsed Laser Photolysis-Pulsed Laser Induced Fluorescence Study?, The Journal of Physical Chemistry A, 110, 6623-6632, doi: 10.1021/jp054688j, 2006.

Draxler, R. R. and Rolph, G. D.: HYSPLIT (HYbrid SingleParticle Lagrangian Integrated Trajectory) Model, Model access via NOAA ARL READY Website (http://www.arl.noaa.gov/ HYSPLIT.php)., model access via NOAA ARL READY Website (http://www.arl.noaa.gov/HYSPLIT.php), 2003.

European Community: Ambient Air Pollution by Mercury - Position Paper on Mercury, Tech. rep., European Commission (Publisher), Office for Official Publications of the European Communities, Brussels, http://europa.eu.int/comm/environment/air/ background.htm\#mercury, ISBN 92-894-2053-7, 2001.

Faganeli, J., Horvat, M., Covelli, S., Fajon, V., Logar, M., Lipej, L., and Cermelj, B.: Mercury and methylmercury in the Gulf of Trieste (northern Adriatic Sea), The Science of The Total Environment, 304, 315-326, doi:10.1016/S0048-9697(02)00578-8, 2003.

Fantozzi, L., Ferrara, R., Frontini, F., and Dini, F.: Factors influencing the daily behaviour of dissolved gaseous mercury concentration in the Mediterranean Sea, Marine Chemistry, 107, 4-12, doi:10.1016/j.marchem.2007.02.008, 2007.

Friedli, H., Arellano, A., Cinnirella, S., and Pirrone, N.: Initial Estimates of Mercury Emissions to the Atmosphere from Global Biomass Burning, Environ. Sci. Technol., 43, 3507-3513, doi: 10.1021/es802703g, 2009.

Goodsite, M. E., Plane, J. M. C., and Skov, H.: A Theoretical Study of the Oxidation of $\mathrm{Hg} 0$ to $\mathrm{HgBr} 2$ in the Troposphere, Environ. Sci. Technol., 38, 1772-1776, doi:10.1021/es034680s, 2004.

Hall, B.: The gas phase oxidation of elemental mercury by ozone, Water, Air, and Soil Pollution, 80, 301-315, 1995.

Hedgecock, I. and Pirrone, N.: Chasing quicksilver: Modeling the atmospheric lifetime of $\operatorname{Hg}(0)$ in the marine boundary layer at 
various latitudes, Environ. Sci. Technol., 38, 69-76, doi:10.1021/ es034623z, 2004.

Hedgecock, I., Pirrone, N., Sprovieri, F., and Pesenti, E.: Reactive gaseous mercury in the marine boundary layer: modelling and experimental evidence of its formation in the Mediterranean region, Atmos. Environ., 37, 41-49, 2003.

Hedgecock, I., Trunfio, G., Pirrone, N., and Sprovieri, F.: Mercury chemistry in the MBL: Mediterranean case and sensitivity studies using the AMCOTS (Atmospheric Mercury Chemistry over the Sea) model, Atmos. Environ., 39, 7217-7230, doi: 10.1016/j.atmosenv.2005.09.002, 2005.

Hedgecock, I. M., Pirrone, N., and Sprovieri, F.: Chasing quicksilver northward: mercury chemistry in the Arctic troposphere, Environ. Chem., 5, 131-134, doi:10.1071/EN08001, 2008.

Holmes, C. D., Jacob, D. J., and Yang, X.: Global lifetime of elemental mercury against oxidation by atomic bromine in the free troposphere, Geophys. Res. Lett., 33, L20808, doi:10.1029/ 2006GL027176, 2006.

Holmes, C. D., Jacob, D. J., Mason, R. P., and Jaffe, D. A.: Sources and deposition of reactive gaseous mercury in the marine atmosphere, Atmos. Environ., 43, 2278-2285, doi:10.1016/ j.atmosenv.2009.01.051, 2009.

Hynes, A. J., Donohoue, D. L., Goodsite, M. E., and Hedgecock, I. M.: Our current understanding of major chemical and physical processes affecting mercury dynamics in the atmosphere and at the air-water/terrestrial interfaces, in: Mercury Fate and Transport in the Global Atmosphere: Emissions, Measurements and Models, edited by: Pirrone, N. and Mason, R. P., chap. 14, 427-457, Springer, http://dx.doi.org/10.1007/ 978-0-387-93958-2_14, ISBN: 978-0-387-93957-5, 2009.

Jung, G., Hedgecock, I. M., and Pirrone, N.: ECHMERIT V1.0 - a new global fully coupled mercury-chemistry and transport model, Geosci. Model Dev., 2, 175-195, 2009.

Kljakovic-Gaspic, Z., Odzak, N., Ujevic, I., Zvonaric, T., Horvat, M., and Baric, A.: Biomonitoring of mercury in polluted coastal area using transplanted mussels, Science of The Total Environment, 368, 199-209, doi:10.1016/j.scitotenv.2005.09.080, 2006.

Kock, H., Bieber, E., Ebinghaus, R., Spain, T., and Thees, B.: Comparison of long-term trends and seasonal variations of atmospheric mercury concentrations at the two European coastal monitoring stations Mace Head, Ireland, and Zingst, Germany, Atmos. Environ., 39, 7549-7556, 2005.

Landis, M. S., Stevens, R. K., Schaedlich, F., and Prestbo, E. M.: Development and Characterization of an Annular Denuder Methodology for the Measurement of Divalent Inorganic Reactive Gaseous Mercury in Ambient Air, Environ. Sci. Technol., 36, 3000-3009, doi:10.1021/es015887t, 2002.

Laurier, F., Mason, R., Whalin, L., and Kato, S.: Reactive gaseous mercury formation in the North Pacific Ocean's marine boundary layer: A potential role of halogen chemistry, J. Geophys. Res.Atmos., 108, 4529, doi:10.1029/2003JD003625, 2003.

Lelieveld, J., Berresheim, H., Borrmann, S., Crutzen, P. J., Dentener, F. J., Fischer, H., Feichter, J., Flatau, P. J., Heland, J., Holzinger, R., Korrmann, R., Lawrence, M. G., Levin, Z., Markowicz, K. M., Mihalopoulos, N., Minikin, A., Ramanathan, V., de Reus, M., Roelofs, G. J., Scheeren, H. A., Sciare, J., Schlager, H., Schultz, M., Siegmund, P., Steil, B., Stephanou, E. G., Stier, P., Traub, M., Warneke, C., Williams, J., and Ziereis, H.: Global Air Pollution Crossroads over the Mediterranean, Sci- ence, 298, 794-799, doi:10.1126/science.1075457, 2002.

Lowe, D., Topping, D., and McFiggans, G.: Modelling multi-phase halogen chemistry in the remote marine boundary layer: investigation of the influence of aerosol size resolution on predicted gas- and condensed-phase chemistry, Atmos. Chem. Phys., 9, 4559-4573, 2009,

http://www.atmos-chem-phys.net/9/4559/2009/.

Mahajan, A. S., Oetjen, H., Lee, J. D., Saiz-Lopez, A., McFiggans, G. B., and Plane, J. M.: High bromine oxide concentrations in the semi-polluted boundary layer, Atmos. Environ., 43, 3811-3818, doi:doi:10.1016/j.atmosenv.2009.05.033, 2009.

Marmer, E., Dentener, F., Aardenne, J. v., Cavalli, F., Vignati, E., Velchev, K., Hjorth, J., Boersma, F., Vinken, G., Mihalopoulos, N., and Raes, F.: What can we learn about ship emission inventories from measurements of air pollutants over the Mediterranean Sea?, Atmos. Chem. Phys., 9, 6815-6831, 2009, http://www.atmos-chem-phys.net/9/6815/2009/.

Mason, R. P.: Mercury emissions from natural processes and their importance in the global mercury cycle, in: Mercury Fate and Transport in the Global Atmosphere: Emissions, Measurements and Models, edited by: Pirrone, N. and Mason, R. P., chap. 7, 173-191, Springer, http://dx.doi.org/10.1007/ 978-0-387-93958-2_7, ISBN: 978-0-387-93957-5, 2009.

Pal, B. and Ariya, P. A.: Gas-Phase HO--Initiated Reactions of Elemental Mercury: Kinetics, Product Studies, and Atmospheric Implications, Environ. Sci. Technol., 38, 5555-5566, doi:10. 1021/es0494353, 2004.

Pirrone, N., Cinnirella, S., Feng, X., Finkelman, R. B., Friedli, H. R., Leaner, J., Mason, R., Mukherjee, A. B., Stracher, G., Streets, D. G., and Telmer, K.: Global Mercury Emissions to the Atmosphere from Natural and Anthropogenic Sources, in: Mercury Fate and Transport in the Global Atmosphere: Emissions, Measurements and Models, edited by: Pirrone, N. and Mason, R. P., chap. 1, pp. 1-47, Springer, http://dx.doi.org/10. 1007/978-0-387-93958-2_7, ISBN: 978-0-387-93957-5, 2009.

Raofie, F. and Ariya, P. A.: Kinetics and products study of the reaction of BrO radicals with gaseous mercury, Journal de Physique IV, 107, 1119-1121, 2003.

Rolph, G. D.: Real-time Environmental Applications and Display sYstem (READY), Website (http://www.arl.noaa.gov/ready.php, nOAA Air Resources Laboratory, Silver Spring, MD., 2003.

Ryaboshapko, A., Bullock, O. R., Jr., Christensen, J., Cohen, M., Dastoor, A., Ilyin, I., Petersen, G., Syrakov, D., Artz, R. S., Davignon, D., Draxler, R. R., and Munthe, J.: Intercomparison study of atmospheric mercury models: 1 . Comparison of models with short-term measurements, Science of The Total Environment, 376, 228-240, doi:10.1016/j.scitotenv.2007.01.072, 2007a.

Ryaboshapko, A., Bullock, O. R., Jr., Christensen, J., Cohen, M., Dastoor, A., Ilyin, I., Petersen, G., Syrakov, D., Travnikov, O., Artz, R. S., Davignon, D., Draxler, R. R., Munthe, J., and Pacyna, J.: Intercomparison study of atmospheric mercury models: 2 . Modelling results vs. long-term observations and comparison of country deposition budgets, Science of The Total Environment, 377, 319-333, doi:doi:10.1016/j.scitotenv.2007.01.071, $2007 \mathrm{~b}$.

Salisbury, G., Williams, J., Holzinger, R., Gros, V., Mihalopoulos, N., Vrekoussis, M., Sarda-Estève, R., Berresheim, H., von Kuhlmann, R., Lawrence, M., and Lelieveld, J.: Ground-based PTR-MS measurements of reactive organic compounds during the MINOS campaign in Crete, July-August 2001, Atmos. 
Chem. Phys., 3, 925-940, 2003,

http://www.atmos-chem-phys.net/3/925/2003/.

Sander, R. and Crutzen, P. J.: Model study indicating halogen activation and ozone destruction in polluted air masses transported to the sea, J. Geophys. Res., 101, 9121-9138, http://dx.doi.org/ 10.1029/95JD03793, 1996.

Sander, R., Kerkweg, A., Jckel, P., and Lelieveld, J.: Technical note: The new comprehensive atmospheric chemistry module MECCA, Atmos. Chem. Phys., 5, 445-450, 2005, http://www.atmos-chem-phys.net/5/445/2005/.

Sandu, A., Daescu, D. N., and Carmichael, G. R.: Direct and adjoint sensitivity analysis of chemical kinetic systems with KPP: Part I-theory and software tools, Atmos. Environ., 37, 5083-5096, doi:10.1016/j.atmosenv.2003.08.019, 2003.

Seigneur, C., Vijayaraghavan, K., and Lohman, K.: Atmospheric mercury chemistry: Sensitivity of global model simulations to chemical reactions, J. Geophys. Res., 111, D22306, doi:10.1029/ 2005JD006780, 2006.

Selin, N. E., Jacob, D. J., Yantosca, R. M., Strode, S., Jaegl, L., and Sunderland, E. M.: Global 3-D land-ocean-atmosphere model for mercury: Present-day versus preindustrial cycles and anthropogenic enrichment factors for deposition, Global Biogeochem. Cy., 22, GB2011, doi:10.1029/2007GB003040, 2008.

Sommar, J., Gårdfeldt, K., Strömberg, D., and Feng, X.: A kinetic study of the gas-phase reaction between the hydroxyl radical and atomic mercury, Atmos. Environ., 35, 3049-3054, 2001.

Sprovieri, F. and Pirrone, N.: Spatial and temporal distribution of atmospheric mercury species over the Adriatic Sea, Environmental Fluid Mechanics, 8, 117-128, doi:10.1007/s10652-007-9045-4, 2008.

Sprovieri, F., Pirrone, N., Gårdfeldt, K., and Sommar, J.: Mercury speciation in the Marine Boundary Layer along a $6000 \mathrm{~km}$ cruise path around the Mediterranean Sea, Atmos. Environ., 37, 63-71, 2003.

Storelli, M.: Potential human health risks from metals $(\mathrm{Hg}, \mathrm{Cd}$, and $\mathrm{Pb}$ ) and polychlorinated biphenyls (PCBs) via seafood consumption: Estimation of target hazard quotients (THQs) and toxic equivalents (TEQs), Food and Chemical Toxicology, 46, 27822788, doi:10.1016/j.fct.2008.05.011, 2008.

Storelli, M., Stuffler, R., and Marcotrigiano, G.: Total and methylmercury residues in tuna-fish from the Mediterranean sea, Food Additives \& Contaminants, 19, 715-720, 2002.
Storelli, M., Giacominelli-Stuffler, R., Storelli, A., and Marcotrigiano, G.: Accumulation of mercury, cadmium, lead and arsenic in swordfish and bluefin tuna from the Mediterranean Sea: A comparative study, Marine pollution bulletin, 50, 1004-1007, 2005.

Storelli, M., Losada, S., Marcotrigiano, G., Roosens, L., Barone, G., Neels, H., and Covaci, A.: Polychlorinated biphenyl and organochlorine pesticide contamination signatures in deep-sea fish from the Mediterranean Sea, Environ. Res., 109, 851-856, doi:10.1016/j.envres.2009.07.008, 2009.

Toyota, K., Kanaya, Y., Takahashi, M., and Akimoto, H.: A box model study on photochemical interactions between VOCs and reactive halogen species in the marine boundary layer, Atmos. Chem. Phys., 4, 1961-1987, 2004, http://www.atmos-chem-phys.net/4/1961/2004/.

Travnikov, O.: Contribution of the intercontinental atmospheric transport to mercury pollution in the Northern Hemisphere, Atmos. Environ., 39, 7541-7548, doi:10.1016/j.atmosenv.2005.07. 066, 2005.

UNEP: Mercury fate and transport in the global atmosphere: Measurements, models and policy implications, UNEP, http: //www.chem.unep.ch/mercury/Sector-Specific-Information/ Fate_and_Transport(1).htm, 2008.

Wängberg, I., Munthe, J., Amouroux, D., Andersson, M., Fajon, V., Ferrara, R., Gårdfeldt, K., Horvat, M., Mamane, Y., Melamed, E., Monperrus, M., Ogrinc, N., Yossef, O., Pirrone, N., Sommar, J., and Sprovieri, F.: Atmospheric mercury at mediterranean coastal stations, Environmental Fluid Mechanics, 8, 101-116, doi:10.1007/s10652-007-9047-2, 2008.

Wiedinmyer, C. and Friedli, H.: Mercury Emission Estimates from Fires: An Initial Inventory for the United States, Environ. Sci. Technol., 41, 8092-8098, doi:10.1021/es071289o, 2007.

Wild, O., Zhu, X., and Prather, M.: Fast-J: Accurate simulation of in-and below-cloud photolysis in tropospheric chemical models, J. Atmos. Chem., 37, 245-282, 2000. 